\title{
Adaptive Development of Higher Education Based on the Project-Oriented Approach
}

\section{Elena Revkova}

\section{Yulia Sokolova}

Orenburg State Institute of Management, Orenburg, Russia

Email: regogim@list.ru

Doi:10.5901/mjss.2015.v6n4s1p230

\section{Abstract}

The article considers the results of studies, carried out by the authors within the framework of a state order from the Russian Ministry of Education and Science. The authors unify such notions as "higher education", "higher educational establishment", "organization", "higher education as an open system". The authors characterize the process of open system adaptation, define the notion of "higher education adaptive development" and give its basic characteristics. Having analyzed some system-wide principles they have outlined the principles of adaptive development of an organization. Regarding the process of managing organization development as activities aimed at maintaining target-oriented changes in the organization parameters and properties in response to the current (anticipated) changes in the external environment, the authors suggest the following hypothesis: if adaptation involves changes based on the principles of cyclicity and impermanence, activities of an organization can be represented as a bulk of projects, aimed at achieving certain targets and goals and limited in time. The Project-Oriented Approach is shown as a methodology of management, helping to link together the linear management of an organization (a permanent process) with managing goal-oriented projects (provisional management structures). This approach helps to assess the adaptive development indicators of a higher educational establishment as a subject of the socio-economic sphere.

Keywords: adaptation, adaptive development, higher education, management, project-oriented approach, indicators, adaptive development principles;

\section{Introduction}

In recent years a greater emphasis has been placed on education. The education system has been perceived as the key factor to form a new level of the economy and society, development of human capital assets - as the main prerequisite for the country's modernization. The characteristic feature of professional learning and higher education has been the ability to adjust to the changing environment, including faster social development, dynamically boosting economy and technology, growing competition, structural changes in the sphere of employment leading to a permanent demand for further professional training and improvement, retraining and higher mobility for professionals.

Aiming at fundamental technological changes in the economy requires both well-trained professionals with new competences and skills and creating innovative ideas and technologies in the higher education system.

The current period of instability, imbalance, emerging new challenges and risks does not permit higher education establishments to be just watching the development of history, taking no steps. Getting adjusted to new conditions and developing within them are the most important challenges faced by the whole system of higher education, as well as by each and every educational establishment within that system.

Modern science has chosen for its first and foremost object of scrutiny the internal development mechanisms, interrelation between multidirectional development processes, synthesis of evolutionary and organizational notions of the development object (Danilov-Danilian, Nekipelov, 2013).

To be able to develop effectively higher educational establishments sometimes have to introduce drastic changes in their "life goals", opting for an appropriate methodology. Nowadays it is not sufficient to provide students with knowledge, we need to keep it up to date, providing broad opportunities for research, putting into effect promising scientific and business ideas.

\section{Methodological Framework}

The authors of the article unify such notions as "higher education", "higher educational establishment", "organization" with 
a higher educational establishment regarded as an open complex dynamically developing system, making part of the socio-economic system (of a country, region, city).

Characterizing the process of open system adaptation as a state of dynamic equilibrium, one can notice certain regular trends among other features of this process (Sokolova, 2014; Revkova, 2014):

- adaptation is an integral system-level process, which could include a short-term adaptation process within a behavioral reaction or a longer process, defined as a state of adapting, or a dynamic integral process, expressed in the ability to adjust to changing conditions;

- adaptation is the goal-oriented process of systems getting adjusted to the variety of their functioning conditions, both external and internal (in relation to the system), as well as actively assimilating the environment;

- adaptivity is an essential attribute of the system being not only adjusting in character but also acting and transforming.

Adaptive development of higher education as an open complex dynamically developing system is defined as transition of an educational establishment from one qualitative state to another on the basis of a long-term program (strategy), resource management and broader opportunities, changed parameters and activity levels, flexible responses to the external environment dynamics.

Adaptive development can also be described as a process of achieving a certain (preset) result by adequately reacting to the changing environment so that to transform the influence of external factors for the purpose of selfprotection.

We can speak of the following features of adaptive development: adaptive development is an active process, consisting in the establishment's strategy-oriented actions with the aim of getting adjusted to new conditions; adaptive development is oriented towards the changing environment with the aim of accommodating the educational establishment's activities to the changing environment and maintaining this ability for a long time (Revkova, 2014).

The idea of the Project-Oriented Approach is based on project management techniques; "a project" is regarded as a goal-oriented and time-limited activity aimed at achieving certain goals. "Project management as a type of management can refer to managing any objects, not only those having express characteristics of a project" (Razu, 2006).

The Project-Oriented Approach is based not on the concept of functions or processes, but on one of a project as a whole, which implies creation of some new, usually unique, nonrecurring product/result or improved product/range of services. This concept is focused on dynamic modeling of the educational establishment structure and management, including diagnostic monitoring, differential diagnostics, risk evaluation and change modeling, as well as innovative project management techniques.

\section{Findings and Discussion}

Adaptation is often seen as "sub-system" inconsistencies, resulting in a search for optimal ways to achieve equilibrium (Ganzen, Yurchenko, 2004; Dikaya, 2007).

Morgan (1986) thinks that an organization is an open system. The idea of its being open emphasizes the relation between the external environment and internal functioning of a system. An organization should follow what is happening in the world around it and be able to meet the demands of the environment.

The ability of a system to develop depends on its ability to make towards more complicated differentiation and integration forms and a greater variety in the system, which helps to overcome difficulties and grab new opportunities, offered by the environment. That implies a cyclical character of those changes.

In the process of its development it is not only a system, set in an environment, that changes but being part of a higher-order system it somehow causes changes in the environment, too. So an organization can be characterized not only as an open system, but as an adaptive dynamic system as well (changing environment - changing organization as an open system - changing environment...). An organization gets adjusted to the changing environment - that somehow causes changes in the organization, the system as a whole or some of its parts (subsystems). On the other hand changes suffered by the organization somehow change (transform) the environment itself.

External factors (political, economic, regional, etc.) influence activities of an organization, varying in dynamics and in the range of influence on the development of the subsystems and processes in the organization. Thus Russia's joining the Bologna Process resulted in modernization of Russian higher education, higher academic mobility of students and professors - in integration of educational establishments; technological updating of the economy has an impact on university education and professional training.

Higher education must be an integral part of the economy, promptly reacting to its structural changes. This is 
especially typical for engineering studies. Faster technological progress, the growing importance of innovations for the economy of the whole country and its parts in the age of globalization, inseparable from developing information technologies, volatile markets have led to the demand for highly-qualified, "flexible" professionals capable of creative and innovative thinking. Higher educational establishments are now facing the challenge of training professionals not only capable of taking the whole of empirical and theoretical knowledge provided by previous generations and assimilating it, but willing to systematically enhance their skills.

The Theory of Management emphasizes some principal factors determining the internal environment of an organization and ensuring adaptive development, which can be classified into the resource provision factors, factors resulting from staff operations and factors related to the management system, including:

- factors in the targets and goals, determining the direction and quality of adaptive development (competitive strategy targets and organization objectives);

- factors determining the ability of an organization to adaptive development, specifically resource provision factors (labor-related, information-related, knowledge-based, economic, financial and other factors);

- factors resulting from staff operations (research, production or management operations);

- factors on the level of basic management functions (planning, administration, motivating and control);

- factors limiting or enhancing adaptive development, such as the staff development factor, the factor on the level of organizational culture, factor of the organization structure flexibility (Anisimova, 2012).

Thus federal universities created in Russia as a result of the regional educational structure optimization and enhancement of the relations between higher educational establishments with the economy and social sphere in the federal districts, direct their activities towards ensuring the programs of socio-economic development of the territories, RF subjects. The key mission of a federal university is to contribute to the strategic development of the territory's society and innovative economy by providing high quality education, research and technological developments, through international integration.

A federal university plays a major role in modernizing the system of education due to involving other educational establishments in its research programs, the activities of a university are aimed at integrating progressive ideas and best practices. One of the principal activities of federal universities, together with contributing to the socio-economic development of territories, is enhancing the innovative processes and competitiveness of the regions through cooperation with industrial enterprises.

Models of universities cooperating with the regions are created under the influence of a number of internal and external factors, each of which (taken together or separately) creates special conditions for functioning of the educational establishment and its interaction with the environment.

Each factor influencing the educational establishment adaptive development is subject to management decisions, which permits to see the whole range of the activity spheres involved (projects) and evaluate the level of development in each of them, arrange priorities in the development of a particular strategic component in accordance with the targeted goals, concentrate on strategic adaptive development projects.

An adaptive system has the following features:

- $\quad$ high flexibility permitting to adjust quickly in the constantly changing internal and external environment;

- high mobility in making management decisions and putting them into practice in accordance with the organization goals;

- $\quad$ current situation adequacy;

- the ability to take into account competition;

- the ability to take into account high professionalism requirements;

- $\quad$ the ability to take into account risks related to the change and development dynamics;

- the ability to take into account the environment indeterminacy.

We define adaptive development management as strategically oriented activities ensuring the targeted changes in the parameters and properties of an organization as a system, as well as its subsystems responding to the current changes in the external environment. The mechanism for managing adaptive development of a higher educational establishment as well as any other organization is based on creating a development strategy. This process involves not only developing strategic plans/programs, but also projects of their implementation, considering the external environment dynamics, strengths and weaknesses of the organization (then and there), current opportunities and risks, as well as would-be changes in the system of the organization or its subsystems ensuring its ability to protect itself and keep functioning for some time.

Periods of minor changes gradually accumulating can from time to time alternate with drastic leaps, dramatically changing the system properties, with each stage evidencing the organization's ability to develop within a certain period of 
time due to certain results received, permitting to develop the current and future spheres of activities, move on to a new stage, and new "products"/services assimilated at the current stage can ensure adaptive development at the following stage.

If we take that adapting involves changes based on the principle of cyclicity and impermanence we can regard an organization's activities as implementing a number of projects.

The advantages of a project are its specificity and concentration on priority issues; its risk is that between the strategy implementation and goals there can exist a probability that after the project has been completed the organization might not be ready for further improvements and development - then a new project will have to be planned and implemented. This can be done permanently with no time limits and certain project matching; such a process is aimed at long-term development of higher education and involves not solving some certain problems but, first of all, contributing to the future development.

Higher education development is taking place through instability, volatility, bifurcations, which determines the choice of priority projects aimed at adaptive development - adaptive changes. Changes as natural effects are connected with creating new projects and ideas. At the same time higher education itself is going through the processes of selforganization regulated by the internal order parameters, expressed in certain traditions, customs, behavioral stereotypes, cultural values. The choice of the adapting mechanism (passive or active adaptation) determines the contents of the organization's every project, responsivity of the "higher educational establishment - project" system is seen in the rate of threat perception being synchronized with the rate of the "key resource" and advantage loss, which lets to change the situation for the better. Higher education often lags behind with its responses, not trying to be pro-active, with the dynamics of social, economic and technological processes outrunning the managemental potential of higher educational establishments.

The Project-Oriented Approach can become the basis for adequate management in a rapidly changing environment, whose objects are projects (administrative, educational, scientific, economic, motivational, etc.).

Gurianova, Zainullina, Meshcheriakova, Nabiyeva, Novikova, Paley, Revkova (2012) think that despite some of the projects being limited in time and risky, other project structures can exist for a long time having no preset duration period. These are structures created for implementing series projects. Such a project structure can be described as a dynamically stable one. Its dynamic stability is ensured by regular target-oriented activities of a project group, aimed at initiating new projects, prolonging the existing ones, monitoring the external environment and taking other steps necessary to maintain the existing projects. Innovative projects set new directions for development, produce images of the future, require reevaluation of previous experiences. Higher education as a self-organizing and developing system can change its structure, create new fluctuations, change the ways of its functioning and initiate new projects.

Inside an educational establishment there can be a number of dynamically stable project sub-structures - internal institutions, ensuring implementation of series of projects. These internal institutions are "profit centers", "quick response centers" permitting to speak of a multidimensional model of a higher educational establishment. In case there is the necessity for structuring activities inside a dynamically stable project there arises the necessity for departmentalization.

The project-oriented approach contributes to creating quite a different philosophy of managing, administering and implementing diversified activities, helps to define goals without cancelling previously set strategic targets, serves as an instrument for developing certain project guidelines/indicators.

The project structure is built not as functions or processes, but as a separate bulk of activities to solve a certain problem, having a fixed beginning and closing. Such a structure is especially convenient in changing conditions, requiring instant flexibility and adaptivity. Thus establishments with strictly regulated business processes use elements of project management if the traditional structure is too cumbersome or does not meet all the goal-oriented requirements. Management based on the Project-Oriented Approach makes it possible to combine the linear management of an organization (a permanent process) with managing goal-oriented projects (provisional management structures). Projects can be oriented towards long-term scientific and technological expectations, development strategies for a country, region, branch or company, etc.

When choosing priority projects there should be considered external and internal guidelines of the educational establishment, major directions of its activities, its role as a socio-economic and political subject of the region, the mission and social responsibility of the higher educational establishment. The project goal can be considered to be the targeted result of the higher educational establishment's activities. The external environment is changing so defining the goals, their adjustment can be situational, systematically proactive, cyclical.

Defining the project goals, steps to be taken to achieve them, the final products/results are largely determined by the following factors:

- the status of the higher educational establishment (the higher educational establishment assesses its position in 
the sphere of scientific, academic and innovative activities);

- $\quad$ attitude to innovations (the higher educational establishment is constantly searching for new ways of engaging in scientific and academic activities; creating new products; entering new markets; using new technologies; using new methods of innovative development management);

- development efficiency (the higher educational establishment determines development goals on the level of interrelation between its activities results and innovative potential, necessary to achieve those results; the most efficient development rate is the one requiring less resources);

- $\quad$ the higher educational establishment potential (assessment of the current potential and comparing it with the amount of resources necessary for the higher educational establishment development; assessment of needs and demands);

- $\quad$ steps aimed at enhancing the potential;

- social responsibility (innovative development being directed towards the results that can benefit the social life, accord with human values, provide the society with high-quality educational services, create a friendly educational environment, help to solve social problems, etc.).

The traditional structure of higher educational establishment activities and project structure can be regarded as static and dynamic components of the whole system managing a project-oriented higher educational establishment. Their importance can change depending on the society and economy development dynamics, plans for future proactive projects and changes expected in future.

The considered Project-Oriented Approach systematizes a number of new internal higher educational establishment structures as a set of "projects". It provides an algorithm for creating projects and offers schemes for managing them. In general the Project-Oriented Approach should be regarded as one of the possible mechanisms for managing a multidimensional higher educational establishment (Grudzinsky, 2004).

The project-oriented management is based on the hypothesis of dynamic stability of a higher educational establishment. At the same time the traditional structure existing inside a project-oriented organization secures accomplishment of its standard goals.

Following the classification by Mintzberg (2001), it must be noted that base units play the leading role in implementing the project, being its "operational nucleus" and "technological subsystem". The role of a base unit is in providing not only the staff, but also scientific, methodological, technological and information resources. Base units can be certain departments, faculties, research centers, laboratories; other dynamically stable project structures can also be necessary for ensuring the implementation of new projects. "Project management is a peculiar management paradigm... consisting in administering, managing and coordinating human and material resources throughout the project life cycle, aimed at efficiently achieving the project goals by applying a system of modern methods, processes and techniques" (Pogorelov, 2012).

In project management greater emphasis is placed on the following functional areas:

- Managing activities related to the subject-matter of the project (contents and limits) - defining goals, results and criteria for the project efficiency evaluation.

- Managing the project time - splitting the scope of works into parts; setting the order for different works to be performed, defining their length and creating a schedule - a calendar for the project; controlling and making amendments to the calendar.

- Managing the project costs - assessing the types and amount of resources (human resources, material resources, information resources, etc.); evaluating the resource and work costs; accounting and control over costs and returns, changes in the budget;

- Quality management - setting the quality standards, related to the project, selecting methods of bringing the quality up to the required level and quality ensuring measures; quality control.

- Personnel management - allocating the roles, responsibilities and relations of coordination and subordination among the project staff; plotting organization and resource diagrams; selection of human resources; building and improving the project team.

- Communication management - identifying the information sources and consumers inside and outside the project, setting the time and frequency of providing information, information delivery methods; describing the types of information spread; managing the procedures of spreading information in the course of project implementation.

- Managing project deviations:

- Managing risks - identifying events which could influence the project, assessing the relation between possible project results and the risky events; building risk-dealing strategies; planning, implementing and 
controlling measures, related to responding to risks.

- Managing problems - identifying problems (functional, technical, etc.), analyzing them, making and implementing decisions, formal shutting down and monitoring the project.

- Managing changes - identifying modifications of the preset parameters, analyzing them, making and implementing decisions, forming, shutting down and monitoring the project changes.

Managing contracts - outlining the required services (Tsibes, Tovb, 2006).

Implementation of an innovative socially-oriented development scenario for higher education can be based on leading growth areas. Long-term (federal) targeted programs may determine the directions for socio-economic development of the RF subjects and municipal structures, while creating favorable environment for implementing investment programs and projects. The leading growth areas can be determined with the help of foresights as well. Using foresights as a projecting tool it is necessary to take into consideration that nowadays the technology development rate around the world is 8-9 years.

Gaponenko (2013) writes that "a foresite is not just a set of methods, updatable bank of knowledge and information; it is not only discussing and searching for development prospects by political subjects with the aim of working out and implementing mobilizing actions but it is a strategic thinking model. There raises the question - how can we clearly differentiate between a foresight, strategic planning and creating a policy? What are their differences in respect of the tools used? A foresight is sort of a bridge between studying the future and creating policies, plans and strategies that is why in the terms of methodology, organization and information it must be oriented towards the needs of those people who make decisions in a particular sphere and, besides, it goes beyond the scope of a conventional planning period".

\section{Conclusion}

Adaptive development of higher education based on the project-oriented approach can have a number of advantages fewer cases of malperformance caused by a lack of coordination between the resources used, a shorter work performance period; a lower total demand for resources and lower total project costs resulting in a cost advantage; project management procedures that can be regulated; investment efficiency assessment and analysis; mathematical methods used to calculate the time, resource and cost parameters of projects; the ability to promptly analyze the influence of changes in the project schedules, resource provision and financing; securing a project performance control structure; accounting and managing project risks; quality control.

Employing the project-oriented approach in managing adaptive development of a higher educational establishment is aimed at more flexible managing processes and efficient resource exploitation in the process of implementing adaptive changes. A project-based management style can significantly increase organization efficiency and improve the performance indicators of a higher educational establishment. The advantage of project management is that it can be used together with other management tools and does not require any significant changes in the higher educational establishment structure and processes. Meanwhile each project can be treated as an individual commercial product appearing to be an organizational and technological complex.

Higher education development based on the Project-Oriented Approach is not only selecting priority projects but also selecting indicators and criteria to assess project performance within a certain period of time depending on the adaptation type.

Prospective (primary) or strategic and tactical adaptation is achieved through strategic vision at all hierarchical levels and selection of tactical projects, with essential prerequisites being as follows: working out the development strategy, allocating missions, building the goal setting tree, including the target values, characterizing the strategic vision; describing the external environment properties, assessing the inner potential (the internal potential and resource analysis must become the starting point of the strategy development, assessing the internal potential and resources and comparing them with those of competitors'), estimating the investment attractiveness/social importance of projects, setting the time parameters for meeting the goals (project implementation).

Secondary adaptation is achieved along the whole development path, it involves implementing tactical projects, selected during primary adaptation, the projects being determined by the real-life environment and development level of an organization. This stage is characterized by analyzing and selecting alternative development strategies, correcting the current project deviations.

Activities of a project-oriented organization can be assessed by their efficiency, cost effectiveness, quality, including labor input quality as the system's ability to function efficiently, profitability, competitiveness.

The activities of a higher educational establishment as a subject of a socio-economic system can be characterized by profits, expenses and employment, including the higher educational establishment's rates as an employment resource; 
the extent to which the establishment influences the economic development of its city or region; its scientific, academic and innovative potential; the contribution made by the educational establishment to social development of the region, to formation and implementation of the regional development strategy, etc.

Working out long-term, mid-term and day-to-day values helps to substantiate strategic, mid-term and day-to-day planning, build a hierarchy of projects linking them together.

Having analyzed the system-wide principles we can speak of the following principles of organization adaptive development:

The Dynamic Balance Principle which is an important prerequisite of an organization's functioning. This principle implies an optimal balance between the system elements, as well between its whole and its parts; an optimal balance between stability and variability, self-organization and disorder; an optimal balance between the system and the external environment.

The Development Principle. The principle involves irreversible target-oriented changes in the system. The system ensures optimal development by reallocating resources from less important to promising high-priority spheres of activities (projects).

The Changeability Principle. According to this principle a system is developing due to its component elements changing or acquiring new properties. Thus the production technology changeability rate is increasing all over the world, accordingly there should also be developing higher education, technologies and contents of educational programs for training professionals capable of dealing with new technologies.

The Adaptation Principle. Every organization (system) seeks to minimize the consequences of internal and external exposures. The system's response to such exposures causes changes. High flexibility of reactions, primarily managerial ones, proves their character to be anti-stress and adaptive.

The Economic Substantiation Principle. This principle ensures decision variability based on taking into account such factors as time, costs and performance results, it ensures achieving the results with minimum resources spent within a set period of time.

The Social Responsibility Principle. Admitting and taking into account social priorities when analyzing, making decisions and implementing projects.

The Project Management Principles. Carrying out changes based on the principle of their impermanence, i.e. clearly setting the starting and closing points of a change in the process of adaptive development, to define activities as a total of projects, a full-fledged model of actions.

The Stabilization Principle. It is about seeking stabilization - stability at different stages of a life cycle; this principle is realized to together with all above-mentioned principles.

\section{References}

Anisimova, O. (2012). "Managing intellectual potential development in the process of industrial enterprises getting adapted to the world market" [Upravlenie razvitiyem intellectualnogo potentsiala v protsesse adaptatsii promishlennikh predpriyaty k mirovomu rinku], Problems of Economics, 1: 124-127

Ganzen, V., Yurchenko V. General editor: Prokhorova A. (2004) The systematic approach to analyzing, describing and researching into mental conditions of a person [Systemny podkhod $k$ analizu, opisaniyu I eksperimentalnomu issledovaniyu psykhicheskikh sostoyany cheloveka], Psychology of states. Chrestomathy. ( pp.189-201) S.-Petersburg: Rech.

Gaponenko, N. (2013). Foresight. Theory. Methodology. Experience. [Foresight. Teoria. Metodologia. Opit.], Moscow: UNITY-DANA

Grudzinsky, A. (2004). Project-oriented university. Professional entrepreneurial organization of a higher educational establishment [Proyektno-orientirovanny universitet. Professionalnaya predprinimatelskaya organizatsia vuza], monograph, N. Novgorod: NNGU.

Gurianova, E., Zaynullina, M., Meshcheriakova, S., Nabiyeva L., Novikova, E., Paley, T., Revkova, E. (2012). Implementation of the project-oriented management model in higher professional education [Realizatsiya proyektno-oriyentirovannoy modeli upravleniya v sfere visshego professionalnogo obrazovaniya], Kazan: Institute of economics and finance K(P)FU.

Danilov-Danilian, V., Nekipelov, A. (2013). New Russian encyclopedia [Novaya Rossiyskaya entsiclopediya], Moscow: 000 «Izdatelstvo «Encyclopedia»: INFRA-M. V. 13 (2).

Dikaya, L. (2007). Adaptation: methodological problems and main research trends [Adaptatsiya: metodologicheskiye problemy i osnovniye napravleniya issledovany], Adaptation psychology and social environment: modern approaches, problems, prospects. $17-42$.

Ksenofontova, A., Revkova, E. (2011) Leading development of higher education based on the project-oriented approach [Operezhayushcheye razvitiye visshey shkoly na osnove proyektno-oriyentirovannogo podhoda], Intelligence. Innovations. Investments. 3: 197-202.

Mintsburg, G. (2001). Structure in a fist. Creating an efficient organization [Struktura v kulake. Sozdaniye effektivnoy organizatsii], S.- 
Petersburg: Peter

Morgan, G. (1986). Images of Organization, Newbury Park, CA: Sage Publications.

Pogorelov, D. (2012). Project management as a tool of bringing up the quality of state-level and municipal management [Proyektnoye upravleniye kak instrument povysheniya kachestva gosudarstvennogo i munitsipalnogo upravleniya], Ecomonics. State. Society. $4(2)$.

Razu, M. (2006). Managing intelligence. Basics of project management: textbook [Upravleniye proyektom. Osnovy proyektnogo upravleniya: uchebnik], Moscow: KNORUS.

Revkova E. (2014). Adaptive organization development as an open dynamic system [Adaptivnoye razvitiye organizatsii kak otkritoy dinamichnoy systemy] Intelligence. Innovations. Investments. 4: 65-72.

Revkova E. (2014). Adaptive organization development as a complex dynamic system: notion, forms, factors, principles Science. Technology and Higher Education: materials of the VI International research and practice conference, Westwood, November 12th-13th, 2014 / publishing office Accent Graphics communications (c. 144-148). Westwood: Canada.

Sokolova, Yu. (2014) The genesis of the notion of "adaptation" [Genezis ponyatiya "adatatsiya"]. Intelligence. Innovations. Investments. 3: $93-99$. 